\title{
EFFECT OF SMOKING METHODS ON THE QUALITY CHARACTERISTICS AND POLYCYCLIC AROMATIC HYDROCARBONS (PAHS) CONTENT OF MULLET FISH (Mugil cephalus ) \\ ${ }^{1}$ Nassar, A.G.; ${ }^{2} \mathrm{lbrahim}$, S. A.; ${ }^{3}$ Abul-Fadl, M. and ${ }^{3} \mathrm{El}-$ Badry, N. \\ ${ }^{1}$ Food Science and Technology Department,Fac.of Agric.,Al-Azhar Univ.,Assiut,Egypt. \\ ${ }^{2}$ Fish Processing and Technology Lab.,National Institute of Oceanography and Fisheries, Cairo,Egypt. \\ ${ }^{3}$ Food Science and Technology Department,Fac.of Agric.,Al-Azhar Univ.,Cairo,Egypt.
}

\begin{abstract}
This work aims to study the effect of smoking methods (traditional and liquid flavouring) on the quality of whole and gutted mullet products and polycyclic aromatic hydrocarbons (PAHs) contents, which may represent carcinogenicity agent for consumer. Also, physico-chemical, bacteriological and sensorial characteristics were determined. Results showed that there was loss in both water and protein content of smoked fish while the content of lipid, salt and ash were increased. In addition, the values of total volatile basic nitrogen (TVB-N), Trimethylamine nitrogen (TMAN) and thiobarbituric acid (TBA) were increased clearly in the samples smoked by traditional method comparing with those smoked by liquid method. Concerning PAHs, it was found 5 components in raw fish flesh and its concentration was bout $0.78 \mu \mathrm{g} / \mathrm{kg}$, and then increased to 9 components after smoking to record 13.37 and $1.72 \mu \mathrm{g} / \mathrm{kg}$ flesh of whole fish smoked by traditional and liquid methods, respectively. The corresponding concentrations of gutted samples smoked by the same previous methods were about 16.36 and $1.80 \mu \mathrm{g} / \mathrm{kg}$ flesh, respectively. Besides, total viable count and halophilic bacteria were decreased in all smoked samples in particularly in gutted samples smoked by traditional method. Moreover, although the traditionally-smoked samples gave high scores for colour, taste and overall acceptability but it contained high level of harmful PAHs as compared with those smoked by liquid method. In conclusion, the authors recommended that smoking of whole and gutted mullet fish by using the liquid method, since, it gave satisfied product characterized with good physico-chemical, bacteriological and sensory attributes with minimum content of PAHs especially with smoked gutted fish as compared with the traditional method.
\end{abstract}

\section{INTRODUCTION}

Smoking methods have been used for centuries as a method for preserving meat and fish. Smoking impregnates the high protein food with aromatic components which lend flavour and colour to the food, and also play a bacteriostatic and antioxidant role (Hattula et al., 2001). Smoking is one of the oldest methods of food preservation and is still widely used in fish processing. However, the conventional smoking process is now being substituted by the use of smoke flavourings. In addition, the quantitative composition of smoke depends upon the kind of wood used and predominantly on the temperature and air supply, but also on the cleaning 
procedure applied after generation (Guillen and Ibargoita, 1998; Stolyhwo and Sikorski, 2005). The preservation effect of salt has been recognized as being due to a decrease in water activity, less availability to microbial attack, and enhancement of functional properties, leading to increase of the shelf-life time. Although salt allows prolonged storage, its contact with fish has been reported to enhance lipid oxidation of the highly unsaturated lipids, directly related to the production of off-flavours and odours, protein denaturation and texture change (Harris and Tall 1994; Leroi and Joffraud,2000). Smoke is produced by the process of incomplete combustion of wood and contains numerous individual components namely: aldehydes, ketones, alcohols, acids, hydrocarbons, esters, phenols, ether, etc (Guillen and Errecalde 2002). These components are transferred to the smoked goods by deposition on their surface and subsequent penetration into their flesh (Doe, 1998). Salting time was an important processing variable influencing product moisture content and the water content or crude protein of fish markedly decreased while ash and $\mathrm{NaCL}$ was increased during smoking (Nktesia-Tabiri and SefaDedeh, 1995 and Ibrahim, 1999). Smoking process was affected on the total volatile base nitrogen (TVB-N) and trimethylamine (TMA). In this concern ELAkel et al. (2005) reported that after smoking of bayad and herring fish the amount of TVB-N and TMA-N was increased. In the traditional technique of smoking to preserve fish, phenolic compounds are of considerable importance for the preservation and organoleptic properties of the smoked products (Kjhallstrand and Petersson, 2001). The relative concentration of phenolic compounds in these products depends on the nature of the wood used in the smoking process, the method of smoke generation and the smoke process used (Guillen and Marzanos, 1999 and Serot et al., 2004). The composition of the smoke and the conditions of processing affect the sensory quality, shelf- life, and wholesomeness of the product. On the other hand, sensory attributes of quality and the shelf- life of smoked fish are affected mainly by the initial microbial contamination, processing conditions, handling of the product after processing and storage temperature (Sikorski et al., 1998)

Polycyclic aromatic hydrocarbons (PAHs) are generally considered to be carcinogenic compounds and, as these also end up in the finished product after smoking. The carcinogenicity of several PAH compounds is known. The most thoroughly studied PAH compounds is benzopyrene (Santodonato et al., 1980). Potential health hazards associated with smoked foods, may be caused by carcinogenic components of wood smoke- mainly $\mathrm{PAH}$ compounds, derivatives of $\mathrm{PAH}$ such as nitro- $\mathrm{PAH}$ or oxygenated $\mathrm{PAH}$, and to a lesser extent also $\mathrm{N}$-nitroso compounds and heterocyclic aromatic amines (Stolyhwo and Sikorski, 2005). Hot smoking used for treating, a main part of meat production, brings about higher concentrations of polycyclic aromatic hydrocarbons than cold smoking . Heavy or wild smoking increases PAHs concentration to high levels. Furthermore, smoke flavourings, which have been produced commercially since about the middle of the last century for use in the meat and fish industries contain only trace amounts of PAHs (Miler and Sikorski, 1990 and Simko, 2002). Therefore, the main objective of this work was to study the effects of smoking processes; traditionally and 
liquid smoke on the quality of smoked mullet (physico-chemical, bacteriological and sensory properties) and to confirm the possible relationship between polycyclic aromatic hydrocarbons (PAHs) content and smoking method applied.

\section{MATERIALS AND METHODS}

\section{Materials}

Fresh fish: mullet fish (Mugil cephalus) with average weight approximately 200-250 g were obtained from Shakshouk Station of Fish Research, El-Fayium Governorate, Egypt, National Institute of Oceanography and Fisheries and transferred within three hours to the laboratory, using ice box. The fish were washed carefully by tap water and half fish were blended, gutted manually and then washed.

Sodium chloride: salt fine refined table (EL-Nasr Co.) was purchased from local market, Nasr City, Cairo, Egypt.

Sawdust: Beech wood sawdust was obtained from the local market, Nasr City, Cairo, Egypt, and then used for the generation of gas smoke in traditional smoking method.

Liquid smoke.the liquid smoke condensate was produced by Namirei Co. LTD., Tokyo, Japan.

\section{Methods \\ Smoking methods:}

Fish were divided into two groups. Each group contained whole and gutted fish. The first group was brined $(20 \% \mathrm{w} / \mathrm{v})$ overnight at $4^{\circ} \mathrm{C}$, rapidly rinsed with tap water, drained at $35^{\circ} \mathrm{C}$ for $3 \mathrm{~h}$ and then cold smoked in a conventional smoking house (rectangular cabinet approximately $55 \times 60 \times 140$ $\mathrm{cm}$. equipped with an automatic control for temperature and humidity) at 22$32^{\circ} \mathrm{C}$ for $7 \mathrm{~h}$ (smoking was done at $22^{\circ} \mathrm{C}$ for $1 \mathrm{~h}$, at $28^{\circ} \mathrm{C}$ for $2 \mathrm{~h}$ and at $32^{\circ} \mathrm{C}$ for $4 \mathrm{~h})$ and $70-90 \%$ relative humidity. The second group was brined $(20 \% \mathrm{w} / \mathrm{v})$ in presence of liquid smoke (at ratio 18 part of brine solution to one part of purified liquid smoke condensate and then heated at $70-80^{\circ} \mathrm{C}$ for $2 \mathrm{~h}$ as reported by EL-Badry (2005) and Varlet et al. (2006). All smoked samples were cooled at room temperature and then packaged. The flow sheet of traditional and liquid smoking methods of whole and gutted mullet fish is illustrated in Fig. (1). 


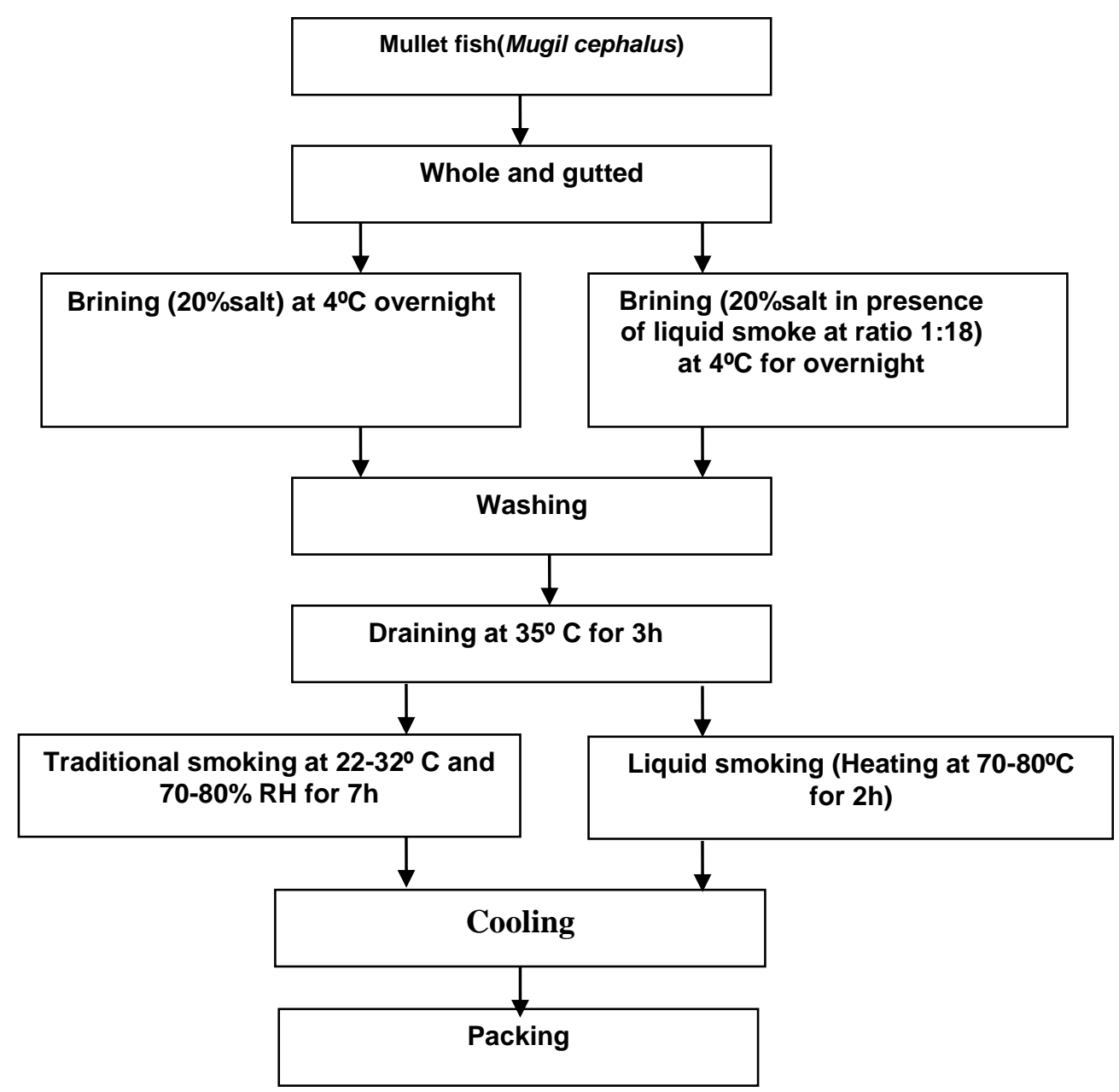

Fig. (1):The flow sheet of traditional and liquid smoking methods of whole and gutted fish.

\section{Analytical methods}

Moisture, crude protein, lipid, ash and Trimethylamine nitrogen (TMA-N) contents were determined according to the methods of AOAC (2000). pH value was measured using a pocket-sized pH meter (Woyewoda, et al., 1986). Total volatile base nitrogen (TVB-N) was determined according to the method described by Botta, et al. (1984). Thiobarbituric acid TBA was determined according to Pearson (1976). Salt content was determined using the method of Anon (1981).

Determination of Polycyclic aromatic Hydrocarbons (PAHs):

a) Extraction: The PAHs were extracted according to the method described by Howared et al. (1966 a\&b) with slight modifications carried out by Egyptian Petroleum Research Institute, Egypt. In brief, sample $(200 \mathrm{~g})$ was digested in ethanol $95 \%(40 \mathrm{ml})$ and $\mathrm{KOH}(25 \mathrm{~g})$ and then distilled 
water $(250 \mathrm{ml})$ were added, and the PAHs partitioned into iso-octan. Interfering materials were removed by column chromatography in florsil60-100 mesh, followed by selective extraction of PAHs into dimethylsulfoxide (DMSO). Further interfering materials where removed by column chromatography on sephadex $\mathrm{LH} 20$, utilizing a solvent mixture of toluene at ratio of $1: 1$ to obtained the purified extracts of $\mathrm{PAHs}$ which used for determination of PAHs components.

b) Determination: The 16 individual PAHs listed by the reference reported by the United States ( US-EPA), in the purified extracts of tested samples were determined qualitatively and quantitatively by using HPLC (model waters HPLC $600 \mathrm{E}$, dual up absorbance detector waters 2487 and auto samplers 717 plus attached to computerized supelco) according to the method mentioned by Lal and Khanna (1996). The PAHs identification and system with millennium 3.2 software PAHs standard were obtained from quantification performed using HPLC. The condition of separation is as follow: Column supelcosil LC/PAH, $5 \mathrm{~m}$ particles, $15 \mathrm{~cm}$ length and $4.6 \mathrm{~mm}$ ID. Mobile phase: Graient acetonitrile; water 60 to $100 \%$ acetonitrile $(\mathrm{v} / \mathrm{v})$ over $45 \mathrm{~min}$. Flow rate: $0.2 \mathrm{~m} / \mathrm{min}, 2-45 \mathrm{~min} .1 .0 \mathrm{ml} / \mathrm{min}$. Detector: it was set at $254 \mathrm{~nm}$.

Microbiological analysis:

Both total viable count and halophilic bacteria were enumerated on plate count agar and the same agar with $10 \%$ salt, respectively as recommended by the Anon (1992).

Sensory evaluation:

Sensory characteristics (colour, odour, tast, texture, tenderness and overall acceptability) were evaluated by ten staff members of the Department of Food Science and Technology Fac. of Agric.AL-Azhar Univ. A ten point scale was used where $10=$ excellent and $1=$ extremely poor. Accuracy and precision were statistically analyzed.

Statistical analysis:

The data analysis of this experiment was carried out. One way analysis of variance and Least Significant Differences test (LSD) were conducted to test significant among the treatment means (Steel and Torrie, $1980)$.Significant was assumed at $(P \leq 0.05)$

\section{RESULTS AND DISCUSSION}

\section{Proximate analysis}

The proximal analysis of raw, salted and smoked samples is presented in Table (1). The initial moisture value of raw mullet was $78.79 \%$, the corresponding mean values for salted whole and gutted samples were $66.78 \%$ and $61.05 \%$, respectively. This loss in moisture is due to the effect of salt osmosis during brining process. In addition, the same trend was found in all smoked samples. This decrease in moisture of smoked samples is due to partial dehydration during smoking. The variation in moisture values for smoked samples is refer to fish from (whole or gutted) and smoking method 
applied (traditional or liquid). Our results are in complete agreement with those of Cardinal et al. (2001), who reported that industrial specifications for "smoked finished products" generally recommended water content in the fish flesh of moisture for smoked fish products less than $65 \%$. Similar findings have been reported by Ibrahim (1999); Kolodziejska et al. (2002); El-Akel et al. (2005) and Goulas and Kontominas (2005).

Table (1): Proximate composition (on wet wt. bases) of raw, salted, traditional and liquid smoked fish products.

\begin{tabular}{|l|c|c|c|c|c|c|c|}
\hline \multirow{2}{*}{$\begin{array}{c}\text { Constituents } \\
\%\end{array}$} & \multirow{2}{*}{$\begin{array}{l}\text { Raw } \\
\text { fish }\end{array}$} & \multicolumn{2}{|c|}{ Salted fish } & \multicolumn{4}{c|}{ Smoked fish } \\
\cline { 3 - 8 } & & Whole & Gutted & Whole & Gutted & Whole & Gutted \\
\cline { 5 - 8 } Moisture & 78.79 & 66.78 & 61.05 & 58.61 & 55.17 & 59.25 & 55.74 \\
& \pm 0.02 & \pm 0.27 & \pm 0.09 & \pm 0.45 & \pm 0.88 & \pm 1.49 & \pm 0.67 \\
\hline \multirow{2}{*}{ Crude protein } & 18.13 & 23.12 & 27.50 & 24.38 & 26.25 & 26.88 & 29.38 \\
& \pm 1.77 & \pm 1.32 & \pm 0.92 & \pm 1.20 & \pm 0.89 & \pm 1.33 & \pm 0.88 \\
\hline \multirow{2}{*}{ Lipid } & 0.79 & 1.56 & 1.19 & 2.49 & 2.43 & 2.09 & 2.02 \\
& \pm 0.13 & \pm 0.20 & \pm 0.04 & \pm 0.09 & \pm 0.18 & \pm 0.45 & \pm 0.16 \\
\hline \multirow{2}{*}{ Ash } & 1.51 & 8.36 & 10.2 & 14.29 & 15.70 & 11.28 & 12.22 \\
& \pm 0.07 & \pm 0.05 & \pm 0.14 & \pm 0.18 & \pm 0.05 & \pm 0.16 & \pm 0.02 \\
\hline \multirow{2}{*}{ Salt } & \multirow{2}{*}{ Traces } & 8.19 & 8.98 & 13.16 & 14.04 & 10.12 & 11.70 \\
& & \pm 1.17 & \pm 0.59 & \pm 0.62 & \pm 0.41 & \pm 1.17 & \pm 0.42 \\
\hline
\end{tabular}

Also, from Table (1), it was found that protein, lipid and ash increased clearly in all salted and smoked samples comparing with initial values. This increase is due to water loss during salting and smoking. In addition, there is little change in salt content for smoked whole and gutted samples either in traditional or liquid smoking methods. The increase in salt content of smoked samples is due to partial dehydration of smoked fish. Furthermore, most of the microorganisms normally associated with fish spoilage are halophobic and will not grow in salt concentration exceeding 5\%. Even though salting effectively prevents the growth of both spoilage and pathogenic bacteria (Horner, 1997; Doe, 1998 and Leroi et al., 2001). However, it has been reported that salt content in fish flesh accelerates oxidation of the highly unsaturated lipids (Aubourg and ugliano, 2002). Similar results were reported by Ibrahim, (1999); Gomez-Guillen et al. (2000); El-Akel et al. (2005) and Yanar et al. (2006). On the other hand, the salt content of smoked fish samples ranged from 10.12 to $14.04 \%$ (on wet wt.) in this study.

\section{Physico-chemical quality attributes}

The physico-chemical quality attributes of studied raw and smoked samples are shown in Table (2).

\section{pH value}

The initial $\mathrm{pH}$ value of raw mullet was 6.14. This value of $\mathrm{pH}$ is in agreement with those found by Metin et al. (2001) and Goulas and Kontominas (2005) for fresh chub mackerel. The $\mathrm{pH}$ values of salted whole and gutted samples were 5.25 and 5.20 , respectively. The $\mathrm{pH}$ decrease in salted samples can be explained by the ionic strength of the solution inside 
of the cells (Leroi and Joffraud, 2000), who reported that salt had a highly significant linear decreasing effect on the $\mathrm{pH}$ value. A progressive decrease was observed in the $\mathrm{pH}$ values of smoked samples by different methods. Its value was remained constant (4.81) in both liquid- smoked whole and gutted samples. On the other side, the $\mathrm{pH}$ values of whole and gutted samples smoked by traditional method were 5.37 and 4.94, respectively. This increase in $\mathrm{pH}$ value of whole and gutted smoked fish by traditional method may be attributed to the production of volatile basic components (Hyytia et al., 1999 and Ruiz-Capillas and Moral, 2001).

\section{Total volatile basic-Nitrogen (TVB-N)}

The initial TVB-N content of raw fish was $11.24 \mathrm{mg} / \mathrm{l00 \textrm {g }}$ flesh, and then increased in salted whole and gutted sample to record 21.47 and 19.60 $\mathrm{mg} / 100 \mathrm{~g}$ flesh, respectively. On the other hand, the value of TVB-N decreased in the samples smoked by liquid method and increased in those smoked by traditional method. Moreover, its value in smoked whole samples was higher than smoked gutted samples. However, the TVB-N content of smoked samples remained lower than permissible limit of $35 \mathrm{mg} / 100 \mathrm{~g}$ flesh set by the EU Anon (1995). In addition, various authors have reported different acceptability levels for TVB-N value ranged from 20 to $40 \mathrm{mg} / 100 \mathrm{~g}$ (Connell, 1990; Lopez- Caballero et al., 2000 and Kim et al., 2002). This wide range reflects smoking method, fish species and whole or gutted form.

Table (2):Physico-chemical quality attributes of raw, salted, traditional and liquid smoked fish products.

\begin{tabular}{|c|c|c|c|c|c|c|c|}
\hline \multirow{3}{*}{ Constituents $\%$} & \multirow{3}{*}{ Raw fish } & \multirow{2}{*}{\multicolumn{2}{|c|}{ Salted fish }} & \multicolumn{4}{|c|}{ Smoked fish } \\
\hline & & & & \multicolumn{2}{|c|}{ Traditional } & \multicolumn{2}{|c|}{ Liquid } \\
\hline & & Whole & Gutted & Whole & Gutted & Whole & Gutted \\
\hline pH value & $\begin{array}{c}6.14 \\
\pm 0.02\end{array}$ & $\begin{array}{c}5.25 \\
\pm 0.03\end{array}$ & $\begin{array}{c}5.20 \\
\pm 0.01\end{array}$ & $\begin{array}{c}5.37 \\
\pm 0.03\end{array}$ & $\begin{array}{c}4.94 \\
\pm 0.02\end{array}$ & $\begin{array}{c}4.91 \\
\pm 0.02\end{array}$ & $\begin{array}{c}4.91 \\
\pm 0.02\end{array}$ \\
\hline 1TVB-N (mg/ 100 g) & $\begin{array}{r}11.24 \\
\pm 1.98 \\
\end{array}$ & $\begin{array}{l}21.47 \\
\pm 1.40\end{array}$ & $\begin{array}{r}19.60 \\
\pm 1.08\end{array}$ & $\begin{array}{l}25.20 \\
\pm 1.88\end{array}$ & $\begin{array}{r}23.80 \\
\pm 0.85\end{array}$ & $\begin{array}{r}16.80 \\
\pm 1.62 \\
\end{array}$ & $\begin{array}{r}16.80 \\
\pm 1.40 \\
\end{array}$ \\
\hline 2TMA-N(mg/ $100 \mathrm{~g})$ flesh & $\begin{array}{c}0.19 \\
\pm 0.04\end{array}$ & $\begin{array}{c}1.05 \\
\pm 0.18 \\
\end{array}$ & $\begin{array}{c}1.02 \\
\pm 0.18\end{array}$ & $\begin{array}{c}0.86 \\
\pm 0.04\end{array}$ & $\begin{array}{c}0.12 \\
\pm 0.08 \\
\end{array}$ & $\begin{array}{c}0.75 \\
\pm 0.03\end{array}$ & $\begin{array}{c}0.02 \\
\pm 0.06\end{array}$ \\
\hline${ }^{3}$ TBA $(\mathbf{m g} / \mathbf{1 0 0} \mathrm{g})$ flesh & $\begin{array}{c}0.43 \\
\pm 0.05\end{array}$ & $\begin{array}{c}1.41 \\
\pm 0.11\end{array}$ & $\begin{array}{r}1.30 \\
\pm 0.07\end{array}$ & $\begin{array}{c}1.61 \\
\pm 0.13\end{array}$ & $\begin{array}{c}1.54 \\
\pm 0.09\end{array}$ & $\begin{array}{c}1.58 \\
\pm 0.08\end{array}$ & $\begin{array}{c}1.50 \\
\pm 0.03\end{array}$ \\
\hline
\end{tabular}

'TVB-N: Total volatile base nitrogen ${ }^{2}$ TMA-N: Trimethylamine nitrogen

3TBA: Thiobarbituric acid

\section{Trimethylamine-Nitrogen (TMA-N)}

From the same table (2), the original value of TMA-N in raw fish flesh was $0.19 / 100 \mathrm{~g}$ and after that, its value increased in salted fish samples to be 1.05 and $1.02 \mathrm{mg} / 100 \mathrm{~g}$ flesh in both whole and gutted samples, respectively (Reddy et al., 1997 and Rodriguez et al., 1999). In contrast, TMA-N content was decreased in all smoked samples particularly in liquid smoked gutted samples $(0.02 \mathrm{mg} / 100 \mathrm{~g}$ flesh). While TMA-N content was 0.86 and $0.75 \mathrm{mg} /$ $100 \mathrm{~g}$ flesh in whole smoked fish, respectively using both traditional and liquid methods. These results are highly lower than the permissible limit of TMA-N (not exceed $10 \mathrm{mg} / 100 \mathrm{~g}$ flesh) reported by Egyptian Standards Specifications (Anon, 1996) for smoked fish. 


\section{Thiobarbituric acid (TBA)}

The initial value of TBA in raw mullet was $0.43 \mathrm{mg}$ Malonaldhyde (MA)/kg flesh (Table, 2). Data show a strong effect of salt and fish form on the values of TBA since it was in salted whole and gutted samples about 1.41 and $1.30 \mathrm{mg} \mathrm{MA} / \mathrm{kg}$ flesh, respectively. A number of studies have demonstrated that salt stimulates lipid oxidation via iron activation. Sodium ions may displace iron from macromolecules such as myoglobin, providing free irons for the catalysis of lipid oxidation (Kanner et al., 1991). On the other hand, the values of TBA were increased in all samples smoked by liquid and gas methods. In addition, whole samples smoked had high values of TBA comparing with gutted samples smoked under the same conditions. The TBA value in the samples smoked by gas method was higher than those of smoked samples by liquid method. The increase in TBA value in the smoked samples may be attributed to the increased oxidation of unsaturated fatty acids as a result of smoking at relatively high temperature (up to $70^{\circ} \mathrm{C}$ ). These results are in agreement with those reported by Goktpe and Moody (1998); Ibrahim (1999); Goulas and Kontominas (2005) and Yanar et al. (2006). In general, these data of TBA values in smoked samples are highly lower than the permissible limit $(4.5 \mathrm{mg}$ $/ \mathrm{kg}$ flesh) reported by Egyptian Standards Specifications (ESS, 1996) for smoked fish.

\section{Polycyclic aromatic hydrocarbons (PAHs)}

The contents of PAHs in the raw, salted and smoked samples are presented in Table (3). Sixteen components of PAHs were detected however; fourteen of them could be identified in the investigated samples. Data showed that the total average concentration of five components in raw fish muscle was $0.78 \mu \mathrm{g} / \mathrm{kg}$ flesh. The presence of these components in raw fish is in agreement with Stolyhwo and Sikorski (2005), who reported that fish and marine invertebrates may naturally contain small amounts of different PAHs absorbed from the environment. However, the concentrations of 11 individual PAHs in raw muscle of mullet have not been detected. Moreover, the concentrations of 9 individual PAHs in traditional-smoked whole and gutted samples were 13.37 and $16.36 \mu \mathrm{g} / \mathrm{kg}$ flesh, respectively.

On the other hand the concentrations of 9 individual PAHs were about 1.72 to $1.81 \mu \mathrm{g} / \mathrm{kg}$ flesh for whole and gutted samples smoked by liquid method, respectively indicating that the treatment of fish by liquid smoking led to lowering the concentration of total PAHs in fish flesh to be more than $90 \%$ of its amount found in fish smoked by traditional method. The dominant components of PAHs were fluorene and acenaphthene in smoked samples by traditional method particularly in smoked gutted samples to be 10.05 and $5.52 \mu \mathrm{g} / \mathrm{kg}$, respectively. In addition, the smoked samples contained much more PAHs than the raw fish muscle, since it increased from 0.02 to about $0.26 \mu \mathrm{g}$ of Penzo(a) pyrene (BaP) $/ \mathrm{kg}$ of product, fish form (whole or gutted), smoking method (traditional and liquid flavorings), composition of smoke and the exposure time to the smoke. Moreover, the concentration of $\mathrm{BaP}$ as marker for PAHs in this study was sharp low comparing with the permissible limit (not exceed $1 \mu \mathrm{g} / \mathrm{kg}$ ) and the upper limit of $0.03 \mu \mathrm{g} / \mathrm{kg}$ for meat products 
treated with smoke preparations as recommended by the European Union (Hartmann, 2000 and Simko,2002). Similar findings were reported by (Kannppan et al., 2000; Hattula et al., 2001 and Varlet et al., 2006).

Table(3):Polycyclic aromatic hydrocarbons (PAHs) concentration $(\mu \mathrm{g} / \mathrm{kg}$ flesh)of raw,traditional and liquid smoked fish products.

\begin{tabular}{|l|c|c|c|c|c|}
\hline \multirow{2}{*}{\multicolumn{1}{c|}{ Component }} & \multirow{2}{*}{$\begin{array}{l}\text { Raw } \\
\text { fish }\end{array}$} & \multicolumn{4}{|c|}{ Smoked fish } \\
\cline { 3 - 6 } & & \multicolumn{2}{|c|}{ Traditional } & \multicolumn{2}{c|}{ Liquid } \\
\cline { 3 - 6 } & Whole & Gutted & Whole & Gutted \\
\hline Naphthalene & ND & 0.42 & ND & ND \\
\hline Acenaphthylene & 0.01 & $\mathrm{ND}$ & 0.12 & $\mathrm{ND}$ & 0.05 \\
\hline Acenaphthene & $\mathrm{ND}$ & 3.60 & 5.52 & $\mathrm{ND}$ & $\mathrm{ND}$ \\
\hline Fluorene & 0.63 & 7.78 & 10.05 & 0.22 & 0.19 \\
\hline Phenethene & $\mathrm{ND}$ & $\mathrm{ND}$ & 0.03 & 0.16 & 0.01 \\
\hline anthracene & 0.02 & 0.07 & 0.02 & 0.10 & 0.02 \\
\hline Fluoranthene & $\mathrm{ND}$ & 0.27 & 0.11 & 0.09 & 1.12 \\
\hline Pyrene & $\mathrm{ND}$ & 1.28 & $\mathrm{ND}$ & 0.19 & 0.17 \\
\hline Benzo(a)anthracene & $\mathrm{ND}$ & $\mathrm{ND}$ & $\mathrm{ND}$ & $\mathrm{ND}$ & $\mathrm{ND}$ \\
\hline Chrysene & $\mathrm{ND}$ & 0.01 & 0.05 & 0.04 & $\mathrm{ND}$ \\
\hline Benzo(b)fluoranthene & $\mathrm{ND}$ & $\mathrm{ND}$ & $\mathrm{ND}$ & 0.03 & 0.04 \\
\hline Benzo(k)fluorancene & $\mathrm{ND}$ & 0.09 & $\mathrm{ND}$ & 0.60 & $\mathrm{ND}$ \\
\hline Benzo(a)pyrene & 0.02 & 0.26 & 0.04 & $\mathrm{ND}$ & 0.13 \\
\hline Dibenzo(a,h)anthracene & 0.10 & $\mathrm{ND}$ & $\mathrm{ND}$ & 0.29 & $\mathrm{ND}$ \\
\hline Benzo(g,h,i)perylene & $\mathrm{ND}$ & $\mathrm{ND}$ & $\mathrm{ND}$ & $\mathrm{ND}$ & $\mathrm{ND}$ \\
\hline Indeno(1,2,3-cd)pyrene & $\mathrm{ND}$ & 0.01 & $\mathrm{ND}$ & $\mathrm{ND}$ & 0.07 \\
\hline TOTAL & 0.78 & 13.37 & 16.36 & 1.72 & 1.80 \\
\hline
\end{tabular}

ND: Not detectable.

\section{Bacteriological aspects}

The bacteriological aspects of raw, salted and smoked fish samples are given in the Table (4). The initial aerobic plate count of raw mullet was 5.45 $\log _{10}$ CFU/g flesh, and was reduced sharply in the whole and gutted salted samples to be 4.70 and $4.52 \log _{10} \mathrm{CFU} / \mathrm{g}$ flesh, respectively. A high decrease in the bacterial load was found in the samples smoked by gas and liquid methods. The reduction rate of bacterial count in all salted and smoked samples is in agreement with Kolodziejska et al. (2002) who reported that the growth retarding and lethal effect of smoking on the spoilage and pathogenic microflora depends on the contents of salt in the watery phase of the product, temperature, humidity, and density of the smoke preparations and the time of temperature of heating. In addition, the gutted samples had low count of bacterial load comparing with whole samples under the same conditions of smoking. However, total bacterial count in the smoked fish products in this study was lower than the recommended count $\left(10^{5} \mathrm{cell} / \mathrm{g}\right)$ set by Egyptian Standards Specifications (Anon, 1996) for smoked fish.

From the same table, the initial count of halophilic bacteria of raw mullet was $4.16 \log _{10} \mathrm{CFU} / \mathrm{g}$ flesh. Also, their counts in the investigated samples have been taken the same trend of total bacterial count. The presence of this bacteria indicated that tolerates the high salt concentration used in this study. Similar results were reported by Skjerdal, (2001). 
Table (4): Bacteriological aspects ( $\log _{10} \mathrm{cfu} / \mathrm{g}$ flesh) of raw, salted, traditional and liquid smoked fish products.

\begin{tabular}{|l|c|c|c|c|c|c|c|}
\hline \multirow{2}{*}{ Bacteriological aspects } & \multirow{2}{*}{ Raw fish } & \multicolumn{2}{|c|}{ Salted fish } & \multicolumn{4}{c|}{ Smoked fish } \\
\cline { 3 - 8 } & & & \multicolumn{2}{|c|}{ Traditional } & \multicolumn{2}{c|}{ Liquid } \\
\cline { 3 - 8 } & & Whole & Gutted & Whole & Gutted & Whole & Gutted \\
\hline Total viable count & 5.45 & 4.70 & 4.52 & 3.96 & 3.40 & 4.59 & 3.72 \\
\hline Halophilic bacterial count & 4.16 & 4.01 & 3.97 & 3.40 & 3.11 & 3.39 & 3.30 \\
\hline
\end{tabular}

\section{Sensory evaluation}

Sensory characteristics i.e. color, odor, texture, taste, and overall acceptability of traditional and liquid-smoked mullet products are given in Table (5). It could be observed that gutted fish samples smoked by gas and liquid method were scored as excellent for acceptability comparing with those whole samples under the same conditions. In addition, the traditional smoking method improved some characteristics such as color, odor, taste and overall acceptability when compared with liquid flavoring method. There are high significant differences $(P \leq 0.05)$ between gutted and whole fish samples smoked by gas and liquid methods. Similar sensory characteristics obtained using the two methods of smoking may be attributed to the adequate cooking provided by the smoking process used (Goulas and Kontominas, 2005 and Varlet et al., 2006).

Table (5): Sensory evaluation of traditional and liquid smoked fish products.

\begin{tabular}{|c|c|c|c|c|c|}
\hline \multirow{3}{*}{ Characteristics } & \multicolumn{4}{|c|}{ Smoking method } & \multirow{3}{*}{ LSD at $P \leq 0.05$} \\
\hline & \multicolumn{2}{|c|}{ Traditional } & \multicolumn{2}{|c|}{ Liquid } & \\
\hline & Whole & Gutted & Whole & Gutted & \\
\hline Color & 6.8 & 9.2 & 6.5 & 8.7 & 0.99 \\
\hline Odor & 6.4 & 9.0 & 6.8 & 8.5 & 0.93 \\
\hline Texture & 6.4 & 8.5 & 7.2 & 8.2 & 0.65 \\
\hline Taste & 7.6 & 8.6 & 6.6 & 8.8 & 0.89 \\
\hline Overall acceptability & 6.2 & 9.0 & 7.0 & 8.0 & 0.46 \\
\hline
\end{tabular}

\section{Conclusion}

This study revealed that smoking of mullet fish by the liquid method was preferred from the point of view of hydrocarbons (PAHs) content, since the amounts of PAHs in fish treated with liquid smoking was lowering more than $90 \%$ that of traditional method. Also, the obtained results showed that the smoked gutted mullet fish was characterized by good quality from the point of view of physico-chemical, bacteriological and sensory properties as compared with smoked whole fish.

\section{REFERENCES}

AOAC (2000): Official Methods of Analysis 17th Ed. Association of Official Analytical International, Gaithersburg M D.USA.

Augbourg,S. and Ugliano,M.(2002): Effect of brine pre-treatment on lipid stability of frozen horse mackerel (Trachurus trachurus). European Food Research and Technology, 215: 91-95. 
Botta,J.R.: Lauder,J.T. and Jewer,M.A. (1984): Effect of methodology on total volatile basic nitrogen (TVB-N) determination as an index of quality of fish Atlantic cod (Gadus morhua). J. Food Sci., 49: 734-736,750.

Cardinal,M.; Konckaert,C., Torrissen, O.; Sigurgisladottir,S.;Morkore, T.; Thomassen, M. and Vallet, J.L.(2001): Relation of smoking parameters to the yield colour and sensory quality of smoked Atlantic salmon (Salmo salar). Food Research International, 34: 537-550.

Connell, J.J. (1990): Methods of assessing and selecting for quality. In control of fish quality ( $3^{\text {rd }}$ ed., pp. 122-150).Oxford: Fishing News Books.

Doe, P.E. (1998): Fish drying and smoking. Production and quality (pp. 13115). Lancaster, PA: Technnomic PubLishing Co. Inc., pp. 89-115.

Anonymous (1995): Total volatile basic nitrogen (TVB-N) limit values for certain categories of fishery products and specifying the analysis methods to be used. Commission Decision 95/149/ESC of 8 March 1995, Official Journal of European Communities. L 97: 84-87.

EL-Akel, T. T. ;Dessouki, T. M. ; Hemeida, H. H. and Arafa, F. A. (2005): Chemical quality attributes of bayad and herring fish during smoking processes and storage at $4^{\circ} \mathrm{C}$. Journal of Home Economics, Minufiya Univ., 15(1-2):1-23.

El-Badry,N. (2005): Study on processing and evaluation of some local meat products. Ph. D. Thesis, Fac. of Agric., Al-Azhar Univ., Egypt.

Anonymous (1996): Egyptian Standards Specifications, concerning smoked fish (No. 288). Egyptian Organization for Standardization and Quality Control, Ministry of Industry and Mineral Wealth. Egypt.

Anonymous (1981): Food and Agriculture Organization. The prevention of losses in cured fish. FAO Fisheries Technical Paper No. 219, pp. 87.

Anonymous (1992): Food and Agriculture Organization. Manuals of Food Quality Control, 4, Rev. 1 Microbiological analysis 1992. Rome.

Goktepe, I. and Moody, M.W. (1998): Effect of modified atmosphere packaging on the quality of smoked catfish. J. Muscle Foods, 9: 375389.

Gomez-Guillen, M.C.; Montero, P.; Hurtado, O. and Borderias,A. J. (2000): Biological characteristics affect the quality of farmed Atlantic salmon and smoked muscle. J. of Food Science, 65 (1): 53-60.

Goulas,A.E. and Kontominas,M.G. (2005): Effect of salting and smoking method on the keeping quality of chub mackerel (Scomber japonicus): biochemical and sensory attributes. Food Chem., 93: 511-520.

Guillen, M. D. and Ibargoitia,M.L. (1998): New components with potential antioxidant and organoleptic properties, detected for first time liquid smoke flavoring preparations. J. Agric. Food Chem., 46: 1276-1285.

Guillen,M. D.and Manzanos,M.G. (1999): Study of the components of a solid smoke flavouring preparation. Food Chemistry, 55, (3): 251-257.

Guillen, M. D. and Errecalde, M. C. (2002): Volatile components of raw and smoked black bream (Brama raii) and rainbow trout (Oncorhynchus mykiss) studied by means of solid phase microextraction and gas chromatography/mass spectrometry. J. Sci. Food \& Agric., 82: 945952. 
Harris,P. and Tall, J. (1994): Rancidity in fish . In Allen J. Hamilton (Ed.), Rancidity in Foods (PP.256-272).London, UK: Chapman and Hall.

Hartmann,K. (2000): Benzo[a]pyren-Bestimmung bei mit Raucharoma geräucherten Fleischerzeugnissen. Deutsche Lebensmittel Rundschau, 96: 163-166.

Hattula, T.; Elfving, K.; Mroueh, U.M. and Luoma, T. (2001): Use of liquid smoke flavouring as an alternative to traditional flue gas smoking of Rainbow trout fillets (Oncorhynchus mykiss). Lebensm.-Wiss.U.Technol., 34: 521-525.

Horner, W.F.A. (1997): Preservation of fish by curing, drying salting and smoking. In G.M. Hall (Ed.), Fish Processing technology ( $2^{\text {nd }}$ ed., $p p$. 32-73). London: Blackie Academic Professional.

Howard,J,W.; Teague,R.T.; White,R.H.; Fry,B.E. (1966a): Extraction and estimation of polycyclic aromatic hydrocarbons in smoked foods. I. General method. J. Association Offic. and Anal. Chem. 49: 595-610.

Howard,J,W.;.; White,R.H.; Fry,B.E.and Turicchi, E.W. (1966b): Extraction and estimation of polycyclic aromatic hydrocarbons in smoked foods. II. Benzo(a)pyrene.. J. Offic. Association and Anal. Chem., 49: 611-617.

Hyytia, E.; Hielm, S.; Mokkila, M.; Kinnunen, A., and Korkeala, H. (1999): Predicted and observed growth and toxigenesis by Clostridium botulinum type $E$ in vacuum-packaged fishery products challenge tests. Inter. J. Food Microbiol., 47: 161-169.

Ibrahim, S. M. (1999): Application of HACCP system in controlling hazards of sum fish products. Ph.D.Thesis,Fac.of Agric., Ain-Shams Univ., Egypt.

Kannappan, S.; Indra-Jasmine, G.; Jeyachandran, P. and Tamil-Selvi, A. (2000): Polyaromatic hydrocarbons in processed fishery products. J. Food Sci. and Technol., 37(6): 596-601.

Kanner, J.; Harel, S. and Jaffe, R. (1991): Lipid per oxidation in muscle food as affected by $\mathrm{NaCl}$. J. Agric. \& Food Chem., 39: 1017-1021.

Kim, Y.M.; Paik, H.D. and Lee, D.S. (2002): Shelf-life characteristics of fresh oysters and ground beef as affected by bacteriocin-coated plastic packaging film. J. Sci. Food \& Agric., 82: 998-1002.

Kjhallstrand, T. and Petersson, G. (2001): Phenolic antioxidants in wood smoke. The Science of the Total Environment, 27: 69-75.

Kolodziejska, I.; Niecikowska, C.; Januszewska, E. and Sikorski, Z.E. (2002): The microbial and sensory quality of Mackerel hot smoked in mild conditions. Lebensmittel-Wissenschaft und-Technologie, 35: 87-92.

Lal,B. and Khanna,S. (1996): Degradition of crude oil by Acinctobacter calcoaceticus and Alcaligenes odorance, J. Appl. Bacter., 81:355-362.

Leroi, F; Joffraud, J.J.; Chevalier,F. and Cardinal,M. (2001): Research of quality indices for cold smoked salamon using astepwise multiple regression of microbiological count and physico-chemical parameters. J. Appl. Microbiol., 90: 578-587.

Leroi, F. and Joffraud, J.J. (2000): Salt and smoke simultaneously affect chemical and sensory quality of cold-smoked salmon during $5{ }^{\circ} \mathrm{C}$ storage predicted using factorial design. J. Food Protection, 63(9): 1222-1227. 
Lopez-Caballero, M.E.; Perez-Mateos, M.; Montero, P. and Borderias, A. J. (2000): Oyster preservation by high-pressure treatment. J. Food Protection, 63(2): 196-201.

Metin, S.; Erkan, N.; Varlike,C. and Aran, N. (2001): Extension of shelf-life of chub mackerel (Scomber japonicus Houttuyn 1780) treated with lactic acid. European Food Research and Technology, 213: 174-177.

Miler, K. M. B. and Sikorski, Z. E. (1990): Smoking. In Z. E. Sikorski (Ed.), Seafood: resources nutritional composition and preservation (PP.163180). Boca Raton: CRC Press.

Nketsia-Tabiri, J. and Sefa-Dedeh, S. (1995): Optimization of process condition quality of salted dried tilapia (Oreochromis nilotica) using response methodology. J. Sci. Food Agric., 69(1): 117-127.

Pearson, D. (1976): The Chemical Analysis of Food. Churchill, New York, London, P. 374-410.

Reddy,N.R.; Roman,M.G.; Villanueva,M.; Solomon,H.M.; Kautter,D.A. and Rhodehamel,E.J. (1997): Shelf-life and Clostridium botulinum toxin development during storage of modified atmosphere-packed fresh catfish fillets. J. Food Sci., 62 (4): 878-884.

Rodriguez,C.J.; Besteiro,I. and Pascual,C. (1999): Biochemical changes in freshwater rainbow trout (Oncorhynchus mykiss) during chilled storage. J. Sci. Food \& Agric., 79: 1473-1480.

Ruiz-Capillas, C. and Moral, A. (2001): Residual effect of $\mathrm{CO}_{2}$ on hake (Merhuccius merluccius L.) stored in modified and controlled atmospheres. European Food Research and Technology, 212: 413420.

Santodonato, J.; Basu,D. and Howard, P. H. (1980): Multimedia human exposure and carcinogenic risk assessment for environmental PAH.In:Bjorseth,A. and Dennis,A. J. (Eds), Poly-nuclear Aromatic Hydrocarbons: Chemistry and Biological Effects. Columbus, Ohio: Battelle Press. Pp.435-454.

Serot, T. Baron, R. Knockaert, C. and Vallet, J. L. (2004): Effect of smoking processes on the content of 10 major phenolic compounds in smoked fillets of herring (Cuplea harengus). Food Chemistry, 85: 111-120.

Sikorski, Z. E.; Harrd, N. Motohiro, T. and Pan,B. S. (1998): Quality. In:Doe,P. E. (Ed.),Fish Drying and Smoking .Production and Quality. Lancaster, Basel: Technomic Publishing Co., Inc.,PP 89-115.

Simko, P. (2002): Determination of polycyclic aromatic hydrocarbons in smoked meat products and smoke flavouring food additives. J. Chromatography B., 770: 3-18.

Skjerdal, T. (2001): Prolonged shelf-life of re-hydrated products of heavy salted cod requires adaptation of the forgoing salting process. $31^{\mathrm{st}}$ WEFTA Meeting, 27-31 May, 2001, Espoo, Finland, L22.

Smiko, P. (2002): Review: determination of polycyclic aromatic hydrocarbons in smoked meat products and smoke flavouring food additives. J. Chromatography B, $770: 3-18$.

Steel, R. G. and Torrie, J. H.(1980): Principles and procedure of statistics. Ed. McGraw-Hill Book Co.,N. Y. 
Stolyhwo, A. and Sikorski, Z.E. (2005): Polycyclic aromatic hydrocarbons in smoked fish - a critical review. Food Chemistry, 91: 303-311.

Varlet,V.; Serot,T. ; Knockaert,C.; Cornet,J.; Cardinal,M.; Monteau,F.; Le Bizec,B. and Prost,C. (2006): Organoleptic characterization and PAH content of salmon (Salmo salar) fillets smoked according to four industrial smoking techniques. J Sci Food Agric (in press) accepted in July 2006.

Woyewoda, A. D.; Show, S. J.; Ke, P. J. and Burns, B. G. (1986): Recommended laboratory methods for assessment of fish quality. Candian Technical Report of Fisheries and Aquatic Sci.,No. 1448.

Yanar, Y.; Çelike, M. and Akamca, E. (2006): Effect of brine concentration on shelf-life oh heat-smoked tilapia (Oreochromis niloticus) stored at $4{ }^{\circ} \mathrm{C}$. Food Chemistry, 97: 244-247.

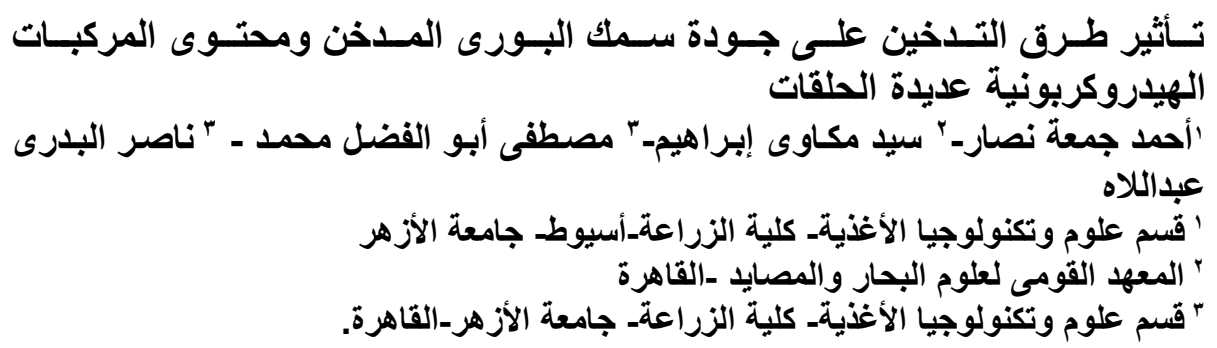

يهدف هذا البحث إلى دراسة تأثير طريقتي التدخين ( الغازي و السـائل ) على جودة سمك البوري

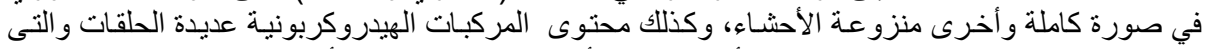

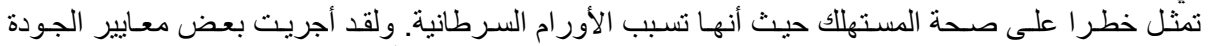

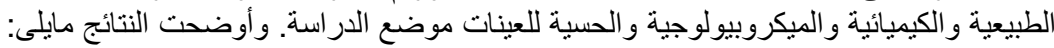

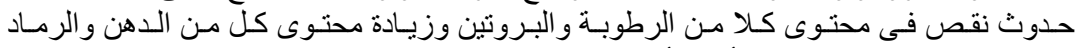

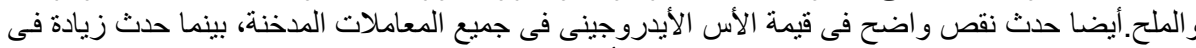

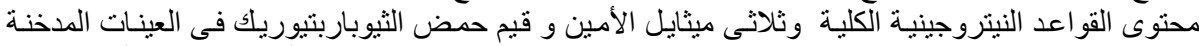

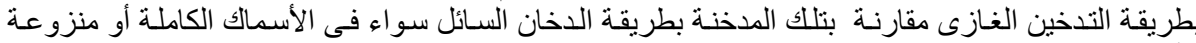

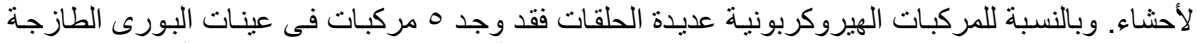

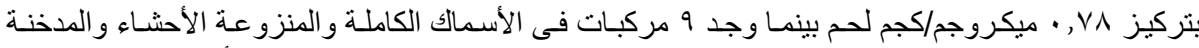

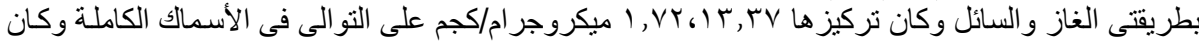

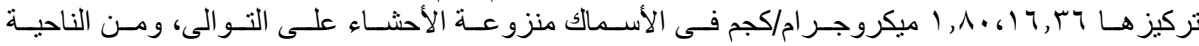

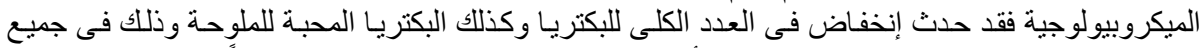

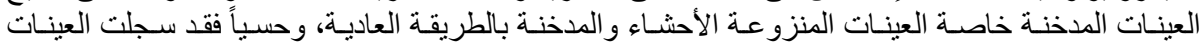

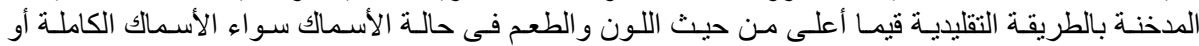

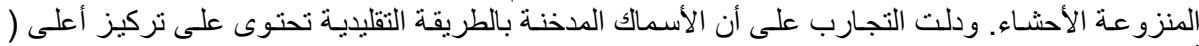

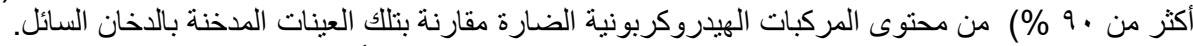

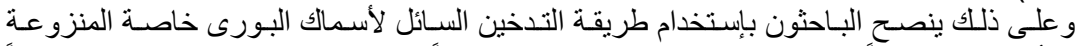

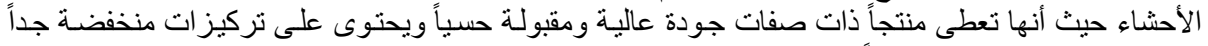

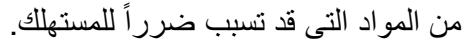


J. Agric. Sci. Mansoura Univ., 32 (2), February, 2007

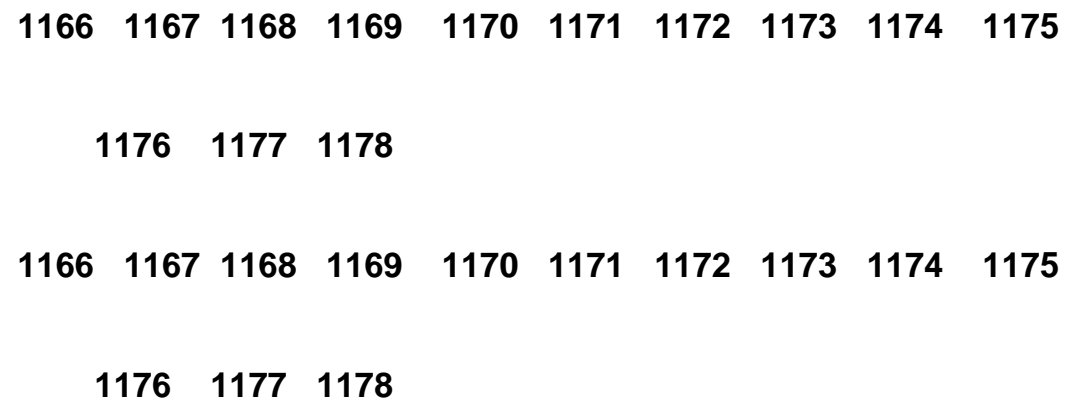

